\title{
Between aesthetics and functionality. Contemporary using of Photovoltaic Systems to create facades
}

\author{
Ilona Szefer ${ }^{1 *}$ \\ ${ }^{1}$ Department of Residential, Industrial, Interior, Rural and Landscape Architecture and Visual Arts, \\ Faculty of Architecture, Wrocław University of Science and Technology, Poland
}

\begin{abstract}
Buildings consume over $40 \%$ [1] of the yearly demand for energy (in IEA member countries). Therefore, it is important to take this fact into account in the designing process - not only in terms of potential savings but also from the point of view of energy acquisition. That is why the external building finishing has an important influence on the energy balance as it may save thermal energy and convert sunlight directly into electricity. It is generally believed that the façade is the showcase of the building. An increasingly common concept for effective building facades, not only those newly-created but also after refurbishment, is photovoltaic panels. Regenerative energy production and architectural designing possibilities are no longer an obstacle. Due to a growing range of available cell technologies (polycrystalline, monocrystalline, high-efficiency and semitransparent), as well as designs (colors, overprints) and parameters (weight, power), their integration with building envelope is not longer an issue. Contemporary Photovoltiaics are designed and manufactured to meet the requirements of designers, builders, investors and the owners. The multifunctionality allows for energy production, as well as for shading, lighting contron and thermal insulation. Using Photovoltiaic systems eneables to create an unique facade construction as well as design.
\end{abstract}

\section{Introduction}

The popularity of renewable energy sources has increased substantially over the last several years. This is related particularly to passing subsequent legal acts, directives as well as local and international rules strictly connected to the energy policies of states and a strong financial support for such solutions.

Cuts, energy consumption control as well as an increased interest of potential customers in using renewable energy sources and a reduction of greenhouse gases constitute one of the world's priorities these days. They are also a necessary condition to meet the requirements of the Kyoto Protocol regarding ongoing climate change [2].

According to the research conducted by the International Energy Agency, the highest growth index of the use of renewable energy sources to date was recorded in 2017 at a level of $25 \%$ of the world's energy production. The greatest contributors were China and the USA, followed by the EU countries, India and Japan [3].

\footnotetext{
*Corresponding author: ilona.szefer@pwr.edu.pl
} 


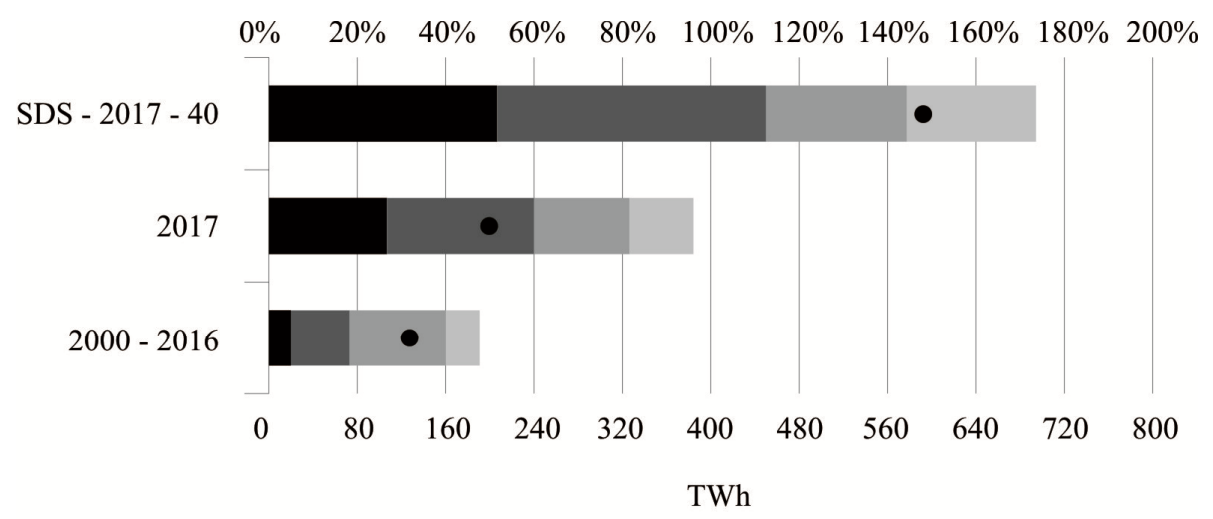

Solar PV Wind $\square$ Hydro $\square$ Other

- Share of net growth (top axis)

Fig. 1. The average annual increase in the global production of energy from renewable sources a comparison and a scenario for the next years [3].

\section{Solar energy - usability of the sunlight potential}

The Sun is the greatest energy source that, providing warmth and light for Earth, made the formation of life possible. The star is about 109 times larger than Earth and at a distance of 150 million $\mathrm{km}$ (the distance changes over Earth's orbital revolutions). As a result, only a small fraction of the Sun's energy reaches the surface of our planet [4]. Solar radiation offers many applications. Plants use it to grow, people take advantage of it in their daily activities and when building eco-friendly green houses. Sunlight also finds an application in the production of one of the most important energy forms - electricity. There are a few methods for its production. Each of them may be applied in large power plants as well as in smaller power supply systems - machines or housing buildings (and not only). They may be an alternative for people who do not want to rely on power supplies from the grid or whose buildings are very distant from the grid and a connection to it would be a substantial cost or even difficult [5].

Solar energy has been used since the ancient times. The simplest way to use it was through solar chimneys. During the day, solar energy heats up the chimney and the air inside. The negative pressure between inlets and outlets helped to enforce air circulation and as a result, the building was cooled. Another method for the use of the Sun discovered in 1839 was the so-called photoelectric or photovoltaic effect. In this case, solar radiation energy is directly converted into electric energy. The father of the method was a French scientist, Alexandre-Edmond Becquerel. The first working photovoltaic cell was constructed by Bell Laboratories in the 50s. An intense development of studies on solar energy dates back to the turn of the 80 s following the 'energy crisis' caused by high prices and the shortage of oil as well as nuclear failures in Harrisburg and Chernobyl. After the crisis was over, conventional energy sources were cheap again and the demand for renewable energy from the Sun decreased [6]. Changes and growing interest in solar energy came back at the beginning of the 21 st century. Since then it has been growing at a yearly rate of $40 \%$ [7]. 


\section{The use of photovoltaic systems in facade creation based on a few selected architectural objects}

Buildings consume over $40 \%[1]$ of the yearly demand for energy (in IEA member countries). Therefore, it is important to take this fact into account in the designing process not only in terms of potential savings but also from the point of view of energy acquisition. That is why the external building finishing has an important influence on the energy balance as it may save thermal energy and convert sunlight directly into electricity. In order to achieve the optimal efficiency of such a system, one needs to take into consideration the location of the future investment with respect to the cardinal directions and the inclination angle of photovoltaic panels.

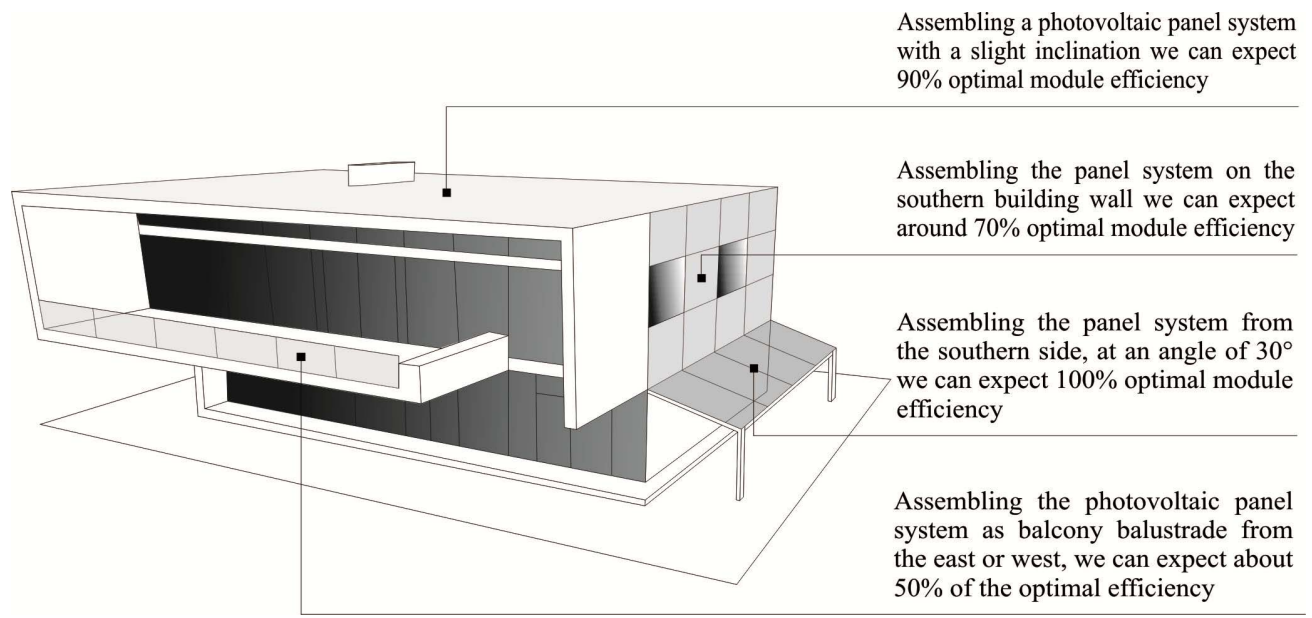

Fig. 2. Possible locations for photovoltaic systems installation, along with optimal module efficiency - based on ertex solar [8].

In architecture, building facades often constitute the most important element of a project since they determine the tone and character of the object being created. They also offer protection against atmospheric conditions. There are many types of facades and the only limitation is in fact the designer's imagination or the financial situation of the investor. Applying photovoltaic systems as facade finishing is especially attractive in high objects where the area of the outer walls is much greater that the roof. Photovoltaic modules fit the facade divisions perfectly, providing extra power.

An ideal example illustrating the connection of energy-saving construction, photovoltaic systems and facade aesthetics is the Art Centre Fondation Pierre Arnaud building situated in Switzerland on lake Louché. Designed by the architect Jean-Pierre Emery, the modern architecture in no way spoils the harmony of a traditional alpine landscape. 

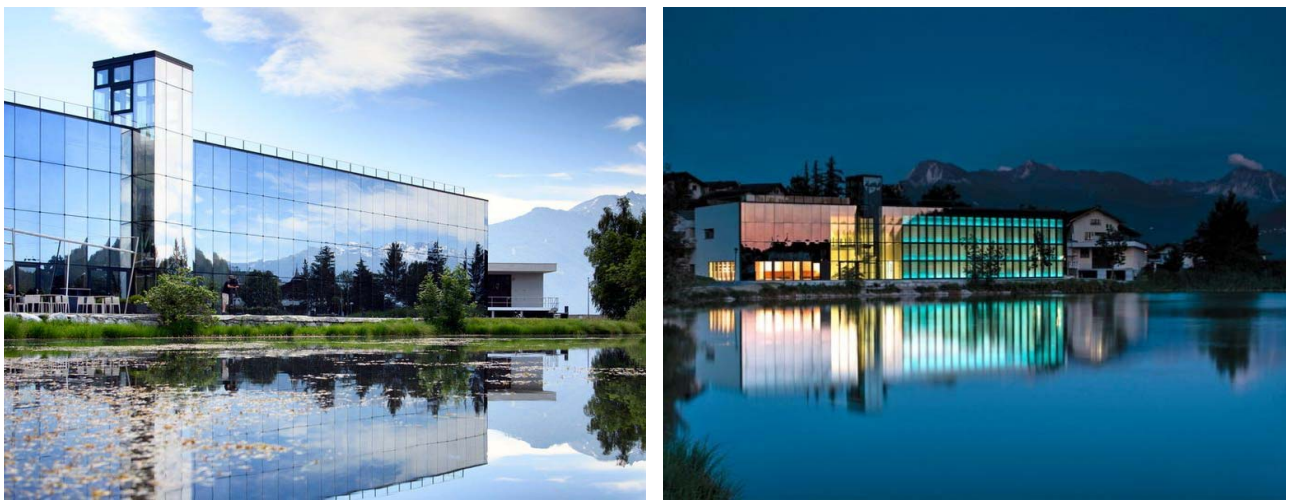

Fig. 3, 4. Facade appearance of photovoltaic panels during the day and at night $[9,10]$.

Thanks to an innovative process aimed at meeting the requirements, such as: reflecting the panorama of the lake and mountains, producing energy using photovoltaic cells, optimal thermal insulation and filtering light to protect exhibits, as well as meeting the Minergie standards (Swiss construction standards for new and modernized objects [11]), Art Centre is a unique object on an European scale. With an area of $250 \mathrm{~m}^{2}$, the facade consists of 84 photovoltaic panels connected with the thermal insulation system composed of nanoparticles, which allowed minimizing the necessary insulation thickness and light penetration. As a result, the year average energy production is about $15,000 \mathrm{kWh}$ and meets the total lighting demand in Art Centre [12].

Another impressive example is the NEW Blauhaus building erected in 2015 in Mönchengladbach at the campus of the Niederrhein University of Applied Sciences. The authors of the project are architects from the German design office Kadawittfeldarchitektur. The object is meant to present innovative solutions in the energy sector. The energy laboratory - having various demands and intensity - is dedicated to students of business administration (specializing in energy management) and for high school and general education school pupils above the age of 10 who apply for university admission. Apart from the NEW energy center's rooms, the Blauhaus building houses different Hochschule Niederrhein education and administration institutions, university library, the "Blauschmiede" centre with offices [13].

A specially carved facade consists of inclined, shiny, blue tiles of glass and photovoltaic elements whose various inclination angles correspond to directions with respect to the sky and incident sunlight, thanks to which the building has a unique character [13, 14].
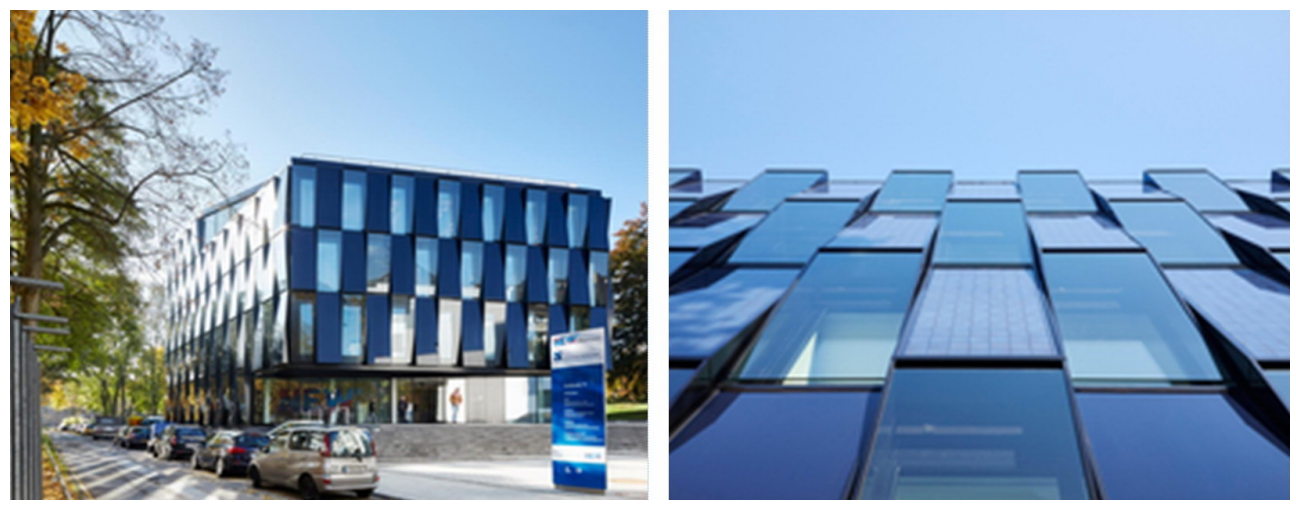

Fig. 5, 6. View of the entire New-Blauhaus building and a fragment of the facade [14]. 
77 photovoltaic modules on the facade and 230 modules on the roof provide enough energy to cover all energetic needs of the building. A consequent implementation of a sustainable and resource-saving approach is reflected by the interior of the new building. The object was built according to the passive house standard and operates in a neutral way in terms of $\mathrm{CO}_{2}$ emissions. This allows minimizing the production of the harmful gas by 110 tones a year. The building yearly energy consumption is covered by the yield of the photovoltaic system. This includes not only the HVAC system (heating and cooling) of the building but also all other electric demands (lighting, computers, other equipment). The building is heated by a brine-water heat pump in connection with an ice storage tank [13, 14].

Worth noticing is also Natura Towers designed by GJP Arquitectos Associados composed of two independent buildings (one of which is the headquarters of the MSF group - a Portuguese building firm). The object is located in Telheiras in Lisbon and stands out with its innovativeness, bio-climatic features and gardens developed around the buildings. Thanks to the beneficial climatic conditions, it was possible to create a biologically active facade with a great variety of plants, from the typical Mediterranean to exotic tropical species [15].
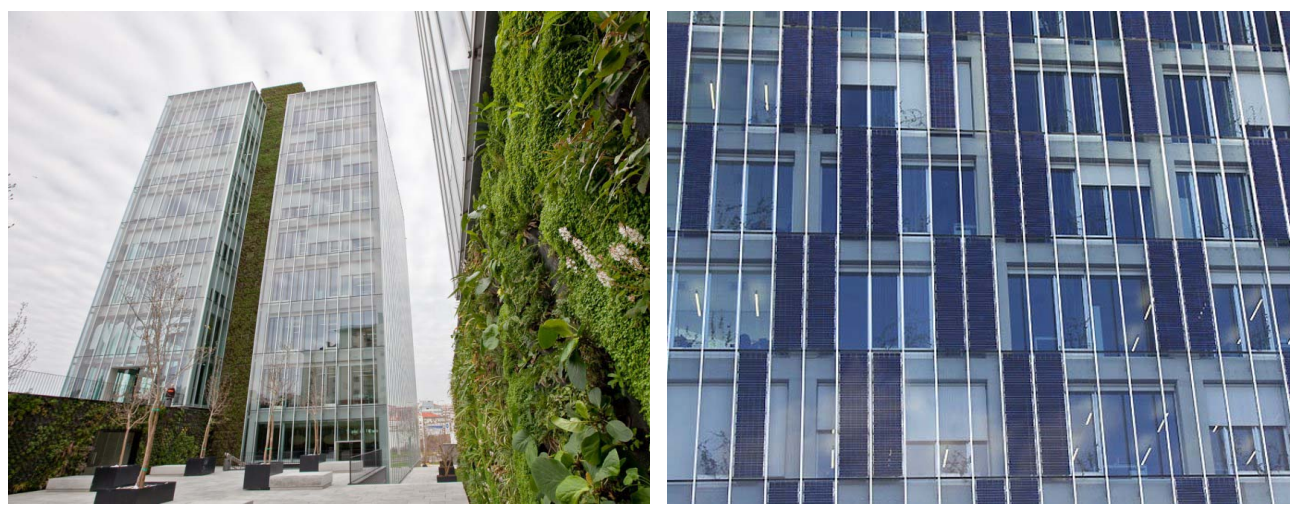

Fig. 7, 8. A view of one of the Natura Towers buildings and a fragment of the façade made of photovoltaic systems $[16,17]$.

The buildings' systems to collect rainwater and store it in the basement for irrigation purposes, photovoltaic panels integrated into the facade (heating and illuminating public spaces) and two-channel ventilation systems enabled significant savings on the operating costs [18].
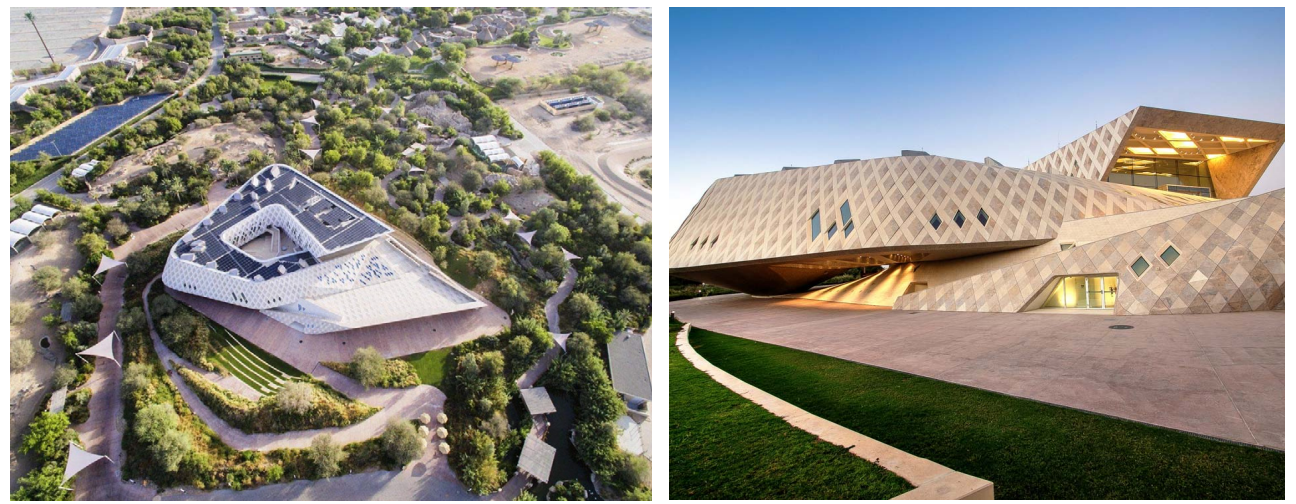

Fig. 9, 10. Sheikh Zayed Desert Learning Center in Al Ain [19]. 
An example of such a project is the building of the Sheikh Zayed Desert Learning Centre in Al Ain (the United Arab Emirates). The education centre constitutes a part of the development of Al ain Wild Life Park \& Resorts, one of the most ambitious projects to protect wildlife in the world. Apart from the protection of endangered species, the building is also expected to serve an educational function. It connects knowledge and science through interactive exhibits, multimedia materials, sample collections, graphics and theatrical performances. All this has been designed by world-class experts and specialists. An inspiration for the authors of the Chalabi Architects \& Partners project, completed in 2013, was the raw landscape surrounding the centre. A result is a sculptural form of the object resembling the Möbius strip, with an inner yard and viewing platforms. The roof was covered with photovoltaic modules highly resistant to atmospheric conditions. The power of installation is $143 \mathrm{kWh}$. The building's function is complemented by the fact that the object is the first building in the United Arab Emirates which received a LEED Platinum certificate (saving energy, water, resources, generating less waste, supporting human health, highly-efficient and economical building) and meets the highest requirements of sustainable development within the Estidama project promoting the policy to create a new balanced framework of the development of Abu Dhabi by 2030, particularly taking into account the environmental, economic and cultural aspects. Thanks to the innovative approach to design and a high-class building management system, the object is expected to decrease the yearly energy consumption by $50 \%, 15 \%$ of energy comes from renewable sources, building waste during construction was minimized and water consumption was reduced [20].

\section{Summary}

The Sun produces an incredible amount of energy every day. That energy could meet the energy needs of every human in the world within one hour. Despite this advantage, solar energy is still a newly-born, developing technology competing with conventional energy sources, such as gas, coal or oil. The challenge is to harvest energy using efficient and costeffective devices which would next convert it into useful heat or electricity [21].

An increasingly common idea for effective building facades, not only those newlycreated but also after refurbishment, is photovoltaic panels. Regenerative energy production and architectural designing possibilities are no longer an obstacle. Due to the growing range of available cell technologies (polycrystalline, monocrystalline, high-efficiency and semitransparent), as well as designs (colors, overprints) and parameters (weight, power), their integration with building envelope is no longer an issue. Contemporary Photovoltiaics are designed and manufactured to meet the requirements of designers, builders, investors, even in the most extreme conditions.

The multi-functionality allows for energy production, as well as for shading, lighting control and thermal insulation. Using Photovoltiaic systems enables the creation of a unique facade construction as well as design. Apart from this, according to the calculations of partners in the project "SmartFlex Solarfacades", supported by the EU, the cost of an elevation made using photovoltaic systems is comparable to the cost of a facade made of traditional, conventional architectural and building solutions, such as stone, brick or metal, and is about $550 € / \mathrm{m}^{2}$. 


\section{Reference}

1. www.iea.org/publications/freepublications/publication/PolicyPathwaysModernisingBuildi ngEnergyCodes.pdf - International Energy Agency (IEA), access: 22.052018

2. Directive 2009.28/EC of the European Parliament and of the council of 23 April 2009 on the promotion of the use of energy from renewable sources and amending and subsequently repealing Directive 2001/77/EC and 2003/30/EC

3. www.iea.org, access: $05.042018 \mathrm{r}$

4. I. F. Mahaney, Solar energy, Rosen Publishing Group,4 (2007)

5. R. Hantula, Solar Power, Infobase Publishing, 4-7 (2010)

6. J. Ollhoff, Solar Power, ABDO Publishing Company, 6-7 (2010)

7. www.hydroglob.pl/blog/2015/04/energetyka-sloneczna-wykorzystywanie-i-perspektywyrozwoju , access: 05.042018

8. www.ertex-solar.at, access: 06.042018

9. www.rts.ch/info/regions/valais/9295470-la-fondation-pierre-arnaud-a-lens-vs-fermeradefinitivement-en-mai.html, access: 07.042018

10. www.crans-montana.ch/fr/Arts--Traditions-483/Fondation-Pierre-Arnaud--77, access: 07.042018

11. www.minergie.ch/de/verstehen/uebersicht, access: 07.042018

12. www.fondationpierrearnaud.ch/en/1015/fpa-center/the-centre,access: 07.042018

13. www.new-energie.de/energieeffizienz/new-blauhaus, access: 07.042018

14. www.kadawittfeldarchitektur.de/projekte/projekt-aktion/show/projekt-titel/newblauhaus.html, access: 07.042018

15. www.verticalgardendesign.com/projects/natura-towers-exterior, access: 07.042018

16. www.mimoa.eu/projects/Portugal/Lisboa/Natura\%20Towers, access: 06.042018

17. www.sapabuildingsystem.com/pt/pt/portefolio/projectos/natura-towers, access: 05.042018

18. www.bprime.pt/en/property/natura-towers, access: 06.042018

19. www.anique-ahmed.com/aerial-photography-dubai, www.alainzoo.ae, access: 05.042018

20. www.ic-ces.at, access: 06.042018

21. Michael E. Mackay, Solar Energy, Oxford University Press, 1-11 (2015). 